\title{
Correlative analysis of the expression of IL-10 and Ki-67 in human cervical cancer and cervical intraepithelial neoplasias and human papillomavirus infection
}

\author{
ZHIHONG MIN*, XIAOWEN PU* and ZHENGRONG GU \\ Department of Gynecology, Shanghai First Maternity and Infant Hospital, \\ Tongji University School of Medicine, Shanghai 200127, P.R. China
}

Received April 2,2018; Accepted September 18, 2018

DOI: $10.3892 / 01.2018 .9520$

\begin{abstract}
This study investigated the expression of IL-10 and $\mathrm{Ki}-67$ in human cervical cancer and cervical intraepithelial neoplasia (CIN) and the correlation with human papillomavirus infection. A total of 110 patients with cervical lesions undergoing surgical treatment in Shanghai First Maternity and Infant Hospital, Tongji University School of Medicine from 2016 to 2017 were selected. Those patients included 36 cases of cervical cancer and 74 cases of CIN. At the same time, 30 cases of chronic cervicitis were selected as the control group. RT-qPCR was used to detect the expression of IL-10 and Ki-67 in cervical tissue. PCR was used to detect HPV infection in cervical tissue. The expression levels of IL-10 and $\mathrm{Ki}-67$ in the cervical cancer and CIN groups were higher than those in the control group. Moreover, the expression levels of IL-10 and Ki-67 in the cervical cancer and CIN II-III groups were higher than those in the CIN I group $(\mathrm{P}<0.05)$. In addition, the expression levels of IL-10 and Ki-67 in the cervical cancer group were significantly higher than those in the CIN II-III group. Furthermore, the expression levels of IL-10 and Ki-67 were positively correlated with HPV infection $(r=0.783$ or $0.712, \mathrm{P}<0.05)$. Finally, the expression levels of IL-10 and Ki-67, and HPV infection in the cervical lesions studied were significantly different. Therefore, combined detection of IL-10, Ki-67 and HPV infection can improve the diagnosis of CIN and early cervical cancer.
\end{abstract}

Correspondence to: Dr Zhengrong Gu, Department of Gynecology, Shanghai First Maternity and Infant Hospital, Tongji University School of Medicine, 2699 Gaoke West Road, Shanghai 200127, P.R. China

E-mail: gzr008@163.com

*Contributed equally

Key words: IL-10, Ki-67, cervical cancer, human papillomavirus infection, correlation analysis

\section{Introduction}

Cervical cancer is a common gynecological malignancy that affects 500,000 new cases and causes approximately 270,000 deaths worldwide every year (1). In recent years, the onset age of cervical cancer is becoming increasingly younger. Cervical cancer lacks obvious symptoms during the early stages, and prognosis of cervical cancer at advanced cervical cancer is poor (2).

The etiology of cervical cancer is complex and diverse. Currently, the main cause of cervical lesions has been proven to be the infection of human papillomavirus (HPV) (3). HPV is a common sexually transmitted virus, with more than 200 subtypes, and those subtypes are divided into the low-risk group and the high-risk group (4). High-risk HPV infection usually causes malignant tumors such as cervical cancer (5), and HPV16 and HPV18 as two high risk types have been confirmed to be related to the occurrence of cervical cancer (6,7). In most cases, viruses can be killed by immune response after HPV infection. Aggravated HPV infection can lead to the progression of cervical disease to cervicitis and cervical intraepithelial neoplasia (CIN). In extreme cases, CIN will further develop into cervical cancer (8). Body's immune response can effectively control precancerous lesions, and changes in immune response may increase the probability of HPV-related diseases (9). Studies have shown that the immunosuppressive factor IL-10 produced by cervical lesions can interact with other types of cytokines to weaken tumor-specific immunity and promote tumorigenesis $(10,11)$. Development of CIN is often characterized by excessive cell proliferation and abnormal differentiation (12). Therefore, markers related to cell proliferation have clinical value for the evaluation of cervical cancer. $\mathrm{Ki}-67$ is a nuclear antigen gene synthesized in the $\mathrm{G} 1, \mathrm{~S}$, and $\mathrm{G} 2 / \mathrm{M}$ phases for the maintenance of cell proliferative activity (13). It can accurately reflect cell proliferation activity and provide important references for the prediction of malignant transformation. Therefore, timely monitoring of HPV infection and IL-10 and Ki-67 expression can provide guidance for the treatment of cervical cancer.

In this study, 110 cases of cervical lesions undergoing surgical treatment (36 cases of cervical cancer and 74 cases of CIN) were selected and 30 cases of chronic cervicitis 
Table I. Clinical data.

\begin{tabular}{|c|c|c|c|c|c|c|}
\hline Groups & Cases & $\begin{array}{c}\text { Age } \\
(\text { mean } \pm \mathrm{SD})\end{array}$ & $\begin{array}{l}\text { Interstitial infiltration } \\
\text { depth }>1 / 2\end{array}$ & $\begin{array}{l}\text { Lymph node } \\
\text { metastasis }\end{array}$ & $\begin{array}{l}\text { SCC-Ag } \\
(\mu \mathrm{g} / 1)\end{array}$ & $\begin{array}{l}\text { CA125 } \\
(\mathrm{U} / \mathrm{ml})\end{array}$ \\
\hline Control & 30 & $42.8 \pm 8.8$ & 0 & 0 & $0.53 \pm 0.05$ & $9.58 \pm 1.55$ \\
\hline CIN I & 34 & $40.3 \pm 7.6$ & 6 & 1 & $1.35 \pm 0.07$ & $15.67 \pm 2.53$ \\
\hline CIN II-III & 40 & $42.1 \pm 7.8$ & 19 & 4 & $7.87 \pm 0.85$ & $43.51 \pm 3.33$ \\
\hline $\mathrm{CC}$ & 36 & $43.5 \pm 6.2$ & 20 & 6 & $10.56 \pm 1.53$ & $52.34 \pm 4.53$ \\
\hline F-value & & 0.016 & $<11.524>$ & $<4.86>$ & 94.347 & 129.686 \\
\hline P-value & & 0.905 & 0.003 & 0.048 & $<0.001$ & $<0.001$ \\
\hline
\end{tabular}

CIN, cervical intraepithelial neoplasia.

were also selected to serve as a the control group to detect the expression of IL-10 and Ki-67, and HPV infection. The correlation of IL-10 and Ki-67 expression with HPV infection was also investigated.

\section{Patients and methods}

Grouping of patients. A total of 110 females with cervical lesions diagnosed in Shanghai First Maternity and Infant Hospital, Tongji University School of Medicine (Shanghai, China) from 2016 to 2017 were included as the observation group. The observation group included 36 cases of cervical cancer (invasive squamous cell carcinoma of the cervix) and 74 cases of CIN patients ( 34 cases of CIN stage I, 18 cases of CIN stage II and 22 cases of CIN stage III). Stages II and III were combined into the CIN II-III group (40 cases), and the control group was 30 patients with chronic cervicitis. All research subjects were suitable for hysterectomy or cervical conization. No preoperative chemotherapy and chemotherapy were performed before surgery. Acute gynecological inflammation was not observed in the patients. There was no statistically significant difference in age between the control group and the observation group (Table I). All patients were reviewed and confirmed by pathologists. All participants were informed and signed informed consent. The study was approved by the Ethics Committee of Shanghai First Maternity and Infant Hospital, Tongji University School of Medicine.

Main reagents. RNA extraction kit, DNA extraction kit, Taq enzyme, and real-time fluorescence quantitative PCR kit were purchased from Sangon Biotech Co., Ltd. (Shanghai, China). Rabbit anti-human IL-10 polyclonal antibody, rabbit anti-human Ki-67 polyclonal antibody (dilution, 1:300; cat no. 20850-1-AP, 27309-1-AP) were purchased from ProteinTech Group, Inc.; Wuhan Sanying Biotechnology (Wuhan, China) and SP universal reagent kits and DAB chromogenic kits were purchased from Boster Biological Technology (Pleasanton, CA, USA). cDNA first-strand synthesis kit was purchased from Takara Bio, Inc. (Otsu, Japan). Primers used in this experiment were all synthesized by GenScript Co., Ltd. (Nanjin, China).

HPV detection. Genomic DNA of the patient's cervical tissue obtained during surgical resection was extracted and used as a template to perform PCR reactions using HPV universal primer MY09/11 (14) to detect whether HPV existed in the patient's cervical tissues. PCR reaction system consisted of $2 \mu \mathrm{l}$ of buffer, $1 \mu \mathrm{l}$ of dNTPs, $0.5 \mu \mathrm{l}$ of upstream and downstream primers, $1 \mu \mathrm{l}$ of template and $0.5 \mu \mathrm{l}$ of Taq enzyme, and $\mathrm{ddH}_{2} \mathrm{O}$ was added to make a final concentration of $20 \mu \mathrm{l}$. PCR reaction conditions were: $94^{\circ} \mathrm{C}$ for $5 \mathrm{~min}$, followed by 30 cycles of $94^{\circ} \mathrm{C}$ for $50 \mathrm{sec}, 55^{\circ} \mathrm{C}$ for $50 \mathrm{sec}$ and $72^{\circ} \mathrm{C}$ for $1 \mathrm{~min}$, and $72^{\circ} \mathrm{C}$ for $10 \mathrm{~min}$. After the PCR reaction, the amplified product was detected by $1.5 \%$ agarose gel electrophoresis and photographed using imaging system.

$R T$ - $q P C R$. RNA extraction kit was used to extract total RNA from cervical tissue, and cDNA was synthesized according to the instructions of cDNA first-strand synthesis kit. RT-qPCR reactions were performed to detect the expression of IL-10 and Ki-67 mRNA using cDNA as template and $\beta$-actin as endogenous control. PCR reaction system was: $10 \mu \mathrm{l}$ of SYBR-Green Master Mix, $0.5 \mu \mathrm{l}$ of upstream and downstream primers, and $1 \mu \mathrm{l}$ of template cDNA, and $\mathrm{ddH}_{2} \mathrm{O}$ was added to make a final volume of $20 \mu \mathrm{l}$. RT-qPCR reaction conditions: $95^{\circ} \mathrm{C}$ for $3 \mathrm{~min}$, followed by 40 cycles of $95^{\circ} \mathrm{C}$ for $30 \mathrm{sec}$ and $58^{\circ} \mathrm{C}$ for $1 \mathrm{~min}$. Sequences of primers are listed in Table II. The experimental results were analyzed using the $2^{-\Delta \Delta \mathrm{Cq}}$ method (15).

Immunohistochemical detection of positive rates of IL-10 and Ki-67 expression. Paraffin embedded cervical tissue were used to make tissue sections with a thickness of $4 \mu \mathrm{m}$ and immunohistochemical SP method was used to detect the positive rate of IL-10 and $\mathrm{Ki}-67$ expression according the manufacturer's instructions. DAB method was used for color development, and yellow granules in the nucleus indicated the positive expression of IL-10 and $\mathrm{Ki}-67$. As a result, the ratio of positive cells to tumor cells $<10 \%$ was determined a negative, and $>10 \%$ was determined as positive.

Statistical analysis. SPSS 17.0 (Beijing Xin Mei Jiahong Technology Co., Ltd., Beijing, China) was used for statistical analysis. Measurement data were expressed as mean \pm SD. Analysis of variance was used for comparisons among multiple groups and Least Significant Difference test was the post hoc test. t-test was used for comparisons between two groups. Chi-square test was used for comparisons of count data. Personality analysis was performed using Pearson's 
Table II. Sequences of primers of RT-qPCR amplification.

\begin{tabular}{lllc}
\hline Genes & Primers & \multicolumn{1}{c}{$\begin{array}{c}\text { Sequences } \\
\left(5^{\prime}-3^{\prime}\right)\end{array}$} & $\begin{array}{c}\text { Length of } \\
\text { product }(\mathrm{bp})\end{array}$ \\
\hline$I L-10$ & F: & ATGCCCCAAGCTGAGAACCAAG & 350 \\
& R: & TCTCAAGGGGCTGGGTCACTATC & \\
Ki-67 & F: & GTCTGTCTTACATGTTATTAATC & 219 \\
& R: & ATCACCAATAAATAGTCTGGGCT & \\
$\beta$-actin & F: & TTCCAGCCTTCCTTCCTGG & 225 \\
& R: & TTGCGCTCAGGAGGAGCAAT & \\
& & &
\end{tabular}

$\mathrm{F}$, forward; R, reverse.

Table III. HPV Infection in cervical tissues (n, \%).

\begin{tabular}{lcc}
\hline Groups & Case & HPV \\
\hline Control & 30 & $3(10)$ \\
CIN I & 34 & $16(47.06)^{\mathrm{a}, \mathrm{b}}$ \\
CIN II-III & 40 & $31(77.5)^{\mathrm{a}-\mathrm{c}}$ \\
CC & 36 & $36(100)^{\mathrm{a}}$ \\
$\chi^{2}$ & & 63.417 \\
P-value & & $<0.001$ \\
\hline
\end{tabular}

${ }^{\mathrm{a}} \mathrm{P}<0.05$, compared with the control group; ${ }^{\mathrm{b}} \mathrm{P}<0.05$, compared with the CC group; ${ }^{\circ} \mathrm{P}<0.05$, compared with CIN I. CIN, cervical intraepithelial neoplasia.

Table IV. The expression of IL-10 in the cervical tissues of each group $[$ mean $\pm \mathrm{SD}, \mathrm{n}(\%)]$.

\begin{tabular}{lccc}
\hline Groups & Cases (n) & $\begin{array}{c}\text { IL-10 } \\
\text { expression level }\end{array}$ & $\begin{array}{c}\text { IL-10 } \\
\text { positive rate }\end{array}$ \\
\hline Control & 30 & $23.63 \pm 3.24$ & $2(6.67)$ \\
CIN I & 34 & $102.08 \pm 10.34^{\mathrm{a}, \mathrm{b}}$ & $6(17.65)^{\mathrm{a}, \mathrm{b}}$ \\
CIN II-III & 40 & $238.36 \pm 15.22^{\mathrm{a}-\mathrm{c}}$ & $22(55)^{\mathrm{a}-\mathrm{c}}$ \\
CC & 36 & $303.24 \pm 18.17^{\mathrm{a}}$ & $29(80.56)^{\mathrm{a}}$ \\
F-value $\left(\chi^{2}\right)$ & & 25658.601 & $<48.35>$ \\
P-value & & $<0.001$ & $<0.001$ \\
\hline
\end{tabular}

${ }^{a} \mathrm{P}<0.05$, compared with the control group; ${ }^{b} \mathrm{P}<0.05$, compared with the CC group; ${ }^{~} \mathrm{P}<0.05$, compared with CIN I. CIN, cervical intraepithelial neoplasia.

correlation analysis. $\mathrm{P}<0.05$ was considered to indicate a statistically significant difference.

\section{Results}

Analysis of clinical data. Clinical data are shown in Table I. There was no difference in age between the observation group (CIN I, CIN II-III and cervical cancer groups) and the control group. In the observation group, interstitial infiltration depth $>1 / 2$ was observed in $40.91 \%$ of patients $(45 / 110)$
Table V. The expression of Ki-67 in the cervical tissues of each group [mean $\pm \mathrm{SD}, \mathrm{n}(\%)]$.

\begin{tabular}{lccc}
\hline Groups & Cases (n) & $\begin{array}{c}\text { Ki-67 expression } \\
\text { levels }\end{array}$ & $\begin{array}{c}\text { Ki-67 positive } \\
\text { expression rate }\end{array}$ \\
\hline Control & 30 & $49.37 \pm 5.24$ & $10(33.33)$ \\
CIN I & 34 & $143.18 \pm 18.54^{\mathrm{a}, \mathrm{b}}$ & $27(79.41)^{\mathrm{a}, \mathrm{b}}$ \\
CIN II-III & 40 & $323.83 \pm 17.23^{\mathrm{a}-\mathrm{c}}$ & $36(90)^{\mathrm{a}-\mathrm{c}}$ \\
CC & 36 & $353.12 \pm 18.19^{\mathrm{a}}$ & $36(100)^{\mathrm{a}}$ \\
F-value $\left(\chi^{2}\right)$ & & 38114.081 & $<55.576>$ \\
P-value & & $<0.001$ & $<0.001$ \\
\hline
\end{tabular}

${ }^{a} \mathrm{P}<0.05$ compared with the control group; ${ }^{\mathrm{b}} \mathrm{P}<0.05$, compared with the $\mathrm{CC}$ group; ${ }^{\mathrm{P}}<0.05$, compared with CIN I. CIN, cervical intraepithelial neoplasia.

Table VI. Correlation between HPV infection and IL-10 and $\mathrm{Ki}-67$ expression in CC tissues (n).

\begin{tabular}{lcrrrrrr}
\hline \multirow{2}{*}{ Groups } & & \multicolumn{2}{c}{ IL-10 expression } & & \multicolumn{2}{c}{ Ki-67 expression } \\
\cline { 3 - 4 } \cline { 6 - 7 } & Cases & Positive & Negative & & Positive & Negative \\
\hline HPV positive & 86 & 57 & 29 & & 86 & 0 \\
HPV negative & 54 & 2 & 52 & & 23 & 32 \\
r & \multicolumn{4}{c}{0.783} & & \multicolumn{2}{c}{0.712} \\
\hline
\end{tabular}

and lymph node metastasis was observed in $10 \%(11 / 110)$ of patients. Significant differences were found between the observation and control groups $(\mathrm{P}<0.05)$. The levels of SCC-Ag and CA125 indicators were significantly higher in the observation group than in the control group $(\mathrm{P}<0.05)$.

Analysis of HPV infection in cervical tissues. PCR detection results showed that the positive rates of HPV in cervical cancer, CIN I and CIN II-III groups were significantly higher than those in the control group (Chi-square values were 11.356, 10.486 and 31.268, respectively; $\mathrm{P}<0.05$ ). The positive rate of HPV in the cervical cancer group was significantly higher than that in the CIN II-III and CIN I groups (Chi-square values were 9.188 and 25.656, respectively; $\mathrm{P}<0.05)$. Finally, the positive rate of the CIN II-III group was significantly higher than that of the CIN I group (Chi-square value was 7.349; P<0.05) (Table III).

Analysis of IL-10 expression in cervical tissue. RT-qPCR analysis showed that the mRNA expression levels of IL-10 in the cervical cancer, CIN I, and CIN II-III groups were significantly higher than those in the control group ( $\mathrm{t}$ values were 25189.812, 6054.89, 21118.557, respectively; $\mathrm{P}<0.05$ ). The expression of IL-10 in the cervical cancer group was significantly higher than that in the CIN II-III and CIN I groups (t values were 8842.564 and 6054.489, respectively; $\mathrm{P}<0.05)$. The expression level of IL-10 in the CIN II-III group was significantly higher than that in the CIN I group ( $t$ value was 30762.692; $\mathrm{P}<0.05)$. The positive rate of IL-10 expression was significantly higher in the cervical cancer, CIN I, and 
CIN II-III groups than that in the control group (Chi-square values were $35.867,3.757$ and 17.77759 , respectively; $\mathrm{P}<0.05$ ). The positive rate of IL-10 expression was significantly higher in the cervical cancer group than in the CIN II-III and CIN I groups (Chi-square values were 27.68 and 10.902 , respectively; $\mathrm{P}<0.05)$. Finally, the positive rate of IL-10 expression was significantly higher in the CIN II-III group than in the CIN I group (Chi-square values was 5.606; $\mathrm{P}<0.05)$ (Table IV).

Analysis of Ki-67 expression in cervical tissue. As shown in Table $\mathrm{V}$, the expression level of $\mathrm{Ki}-67$ was higher in the cervical cancer, CIN I, and CIN II-III groups than in the control group ( $\mathrm{t}$ values were 61329.613, 571.8836 and 95665.658, respectively; $\mathrm{P}<0.05$ ). The expression level of Ki-67 was significantly higher in the cervical cancer group than in the CIN II-III and CIN I groups (t values were 2075.601 and 59985.685, respectively; $\mathrm{P}<0.05$ ). The expression level of $\mathrm{Ki}-67$ was significantly higher in the CIN II-III group than in the CIN I group ( $t$ value $46500.616 ; \mathrm{P}<0.05$ ). The positive rate of $\mathrm{Ki}-67$ expression was significantly higher in the cervical cancer, CIN, and CIN II-III groups than in the control group (Chi-square values were 30.249, 15.877 and 34.435, respectively; $\mathrm{P}<0.05)$. The positive rate of $\mathrm{Ki}-67$ expression was significantly higher in the cervical cancer group than in the CIN II-III and CIN I groups (Chi-square values were 3.849 and 6.949, respectively; $\mathrm{P}<0.05)$. Finally, the positive rate of Ki-67 expression was significantly higher in the CIN II-III group than in the CIN I group (Chi-square value was 4.18; $\mathrm{P}<0.05)$.

Correlation between IL-10 and Ki-67 expression and HPV infection in cervical cancer tissues. Among 110 cases of cervical lesions and 30 cases of chronic cervicitis, 86 cases were HPV-positive and 54 cases were HPV-negative. Correlation analysis showed that the levels of IL-10 and Ki-67 expression were positively correlated with HPV infection $(\mathrm{r}=0.783,0.712$; $\mathrm{P}<0.05)$ (Table VI).

\section{Discussion}

Cervical cancer is a serious threat to women's health, and the incidence rate is gradually increasing. At present, the conventional clinical treatment methods for this disease are surgery, radiotherapy, and chemotherapy. Although these treatments have a certain therapeutic effect, recurrence and metastasis after treatment still occur, especially in patients with advanced cervical cancer (16). Therefore, early diagnosis and treatment of cervical cancer is still critical.

HPV is a spherical DNA virus that causes squamous epithelium proliferation in the skin mucous membranes (17). Studies have shown that HPV infection is closely related to the occurrence of cervical cancer, in which infection of high-risk HPV plays an important role (18). High-risk HPV16 and HPV18 infection rate in cervical cancer patients was 50 and $20 \%$, respectively (19). DNA fragment of high-risk HPV inserts into host genome to disrupt the stability of the genome, so as to induce neoplastic transformation (20). This study found that the positive rate of HPV in the cervical cancer group was $100 \%$, which was significantly higher than that of the CIN I, CIN II-III and control groups $(\mathrm{P}<0.05)$. The positive rate of HPV in the CIN II-III group was significantly higher than that in the CIN I and control groups $(\mathrm{P}<0.05)$. The positive rate of HPV in the CIN I group was significantly higher than that in the control group $(\mathrm{P}<0.05)$. Our findings showed that, with the development of cervical lesions, the infection rate of HPV increases. All cervical cancer patients were infected with HPV, indicating that HPV infection is closely related to the occurrence and development of cervical cancer. Vuitton et al (21) reported that the onset of cervical cancer patients is associated with high-risk HPV infection, suggesting that high-risk HPV is an important factor in the onset of cervical cancer.

Studies have shown that the proportion of $\mathrm{T}$ cells secreting IL-10 is higher in patients infected with HPV virus than in non-infected individuals (22), revealing that the development of cervical cancer is related to high level of IL-10. The role of IL-10 is to inhibit the production of antitumor factors, hinder the role of monocyte-macrophages, and accelerate tumor growth and proliferation (23). In addition, studies have shown that in cervical lesions, the increase in IL-10 is mainly caused by local lesions, and is not related to the plasma content (21). Therefore, the present study examined the expression of IL-10 in cervical tissue. Results showed that the mRNA expression levels of IL-10 in the cervical cancer, CIN I, and CIN II-III groups were significantly higher than those in the control group $(\mathrm{P}<0.05)$. The expression level of IL-10 in the cervical cancer group was significantly higher than that in the CIN II-III and CIN I groups $(\mathrm{P}<0.05)$. The expression level of IL-10 in the CIN II-III group was significantly higher than that in the CIN I group $(\mathrm{P}<0.05)$, indicating that, with the development of cervical lesions, the expression level of IL-10 also increased. The positive rate of IL-10 expression was also significantly different among the cervical cancer, CIN I, CIN II-III and control groups $(\mathrm{P}<0.05)$. With the increase of cervical lesions, the IL-10 positive expression rate also increased. Those data suggest that expression of IL-10 is closely related to the development of cervical lesions. Correlation analysis showed that the IL-10 expression was positively correlated with HPV infection. Our study confirmed that the expression of IL-10 is closely related to the occurrence and development of cervical cancer, which is consistent with the findings of Barbisan et al (24).

$\mathrm{Ki}-67$ expression is closely related to cell mitosis and cell proliferation. Ki-67 can be used as a criterion to distinguish different degrees of benign and malignant tumors (25). Results of this study showed that expression level of Ki-67 in the cervical cancer, CIN I, and CIN II-III groups were higher than those in the control group $(\mathrm{P}<0.05)$. The expression level of Ki-67 in the cervical cancer group was significantly higher than in the CIN II-III and CIN I groups $(\mathrm{P}<0.05)$. The expression level of Ki-67 in the CIN II-III group was significantly higher than that in the CIN I group $(\mathrm{P}<0.05)$, indicating that the expression level of Ki-67 increased with the development of cervical cancer. Furthermore, the positive rate of Ki-67 expression increased significantly, with increase in severity of cervical lesions (from CIN I and CIN II-III groups to cervical cancer group, $\mathrm{P}<0.05$ ). The correlation analysis showed that the expression of Ki-67 was positively correlated with HPV infection. The above data indicated that the expression of $\mathrm{Ki}-67$ is closely related to the occurrence and 
development of cervical cancer, which is consistent with the findings of Muñoz et al (26).

In conclusion, HPV infection rate in cervical cancer tissues is high, and the expression levels of IL-10 and $\mathrm{Ki}-67$ increase with increased severity of cervical lesions, and the expression levels of IL-10 and Ki-67 are positively correlated with HPV infection rate. Therefore, detection of the IL-10 and Ki-67 expression and HPV infection may provide references for the diagnosis of cervical cancer.

\section{Acknowledgements}

Not applicable.

\section{Funding}

This study was supported by Shanghai municipal medical and health discipline construction projects (no. 2017ZZ02015).

\section{Availability of data and materials}

The datasets used and/or analyzed during the present study are available from the corresponding author on reasonable request.

\section{Authors' contributions}

ZM drafted this study. ZM and XP detected HPV and were responsible for RT-qPCR. ZG contributed to the performance of immunohistochemical detection. All authors have read and approved the final manuscript.

\section{Ethics approval and consent to participate}

The study was approved by the Ethics Committee of Shanghai First Maternity and Infant Hospital, Tongji University School of Medicine (Shanghai, China). Signed informed consents were obtained from the patients or guardians.

\section{Patient consent for publication}

Not applicable.

\section{Competing interests}

The authors declare that they have no competing interests.

\section{References}

1. Pedroza-Torres A, Campos-Parra AD, Millan-Catalan O, Loissell-Baltazar YA, Zamudio-Meza H, Cantú de León D, Montalvo-Esquivel G, Isla-Ortiz D, Herrera LA, Ángeles-Zaragoza Ó, et al: MicroRNA-125 modulates radioresistance through targeting p21 in cervical cancer. Oncol Rep 39: $1532-1540,2018$

2. Ho CM, Chien TY, Huang SH, Wu CJ, Shih BY and Chang SC: Multivariate analysis of the prognostic factors and outcomes in early cervical cancer patients undergoing radical hysterectomy. Gynecol Oncol 93: 458-464, 2004.

3. Hildesheim A, Gonzalez P, Kreimer AR, Wacholder S, Schussler J, Rodriguez AC, Porras C, Schiffman M, Sidawy M, Schiller JT, et al; Costa Rica HPV Vaccine Trial (CVT) Group: Impact of human papillomavirus (HPV) 16 and 18 vaccination on prevalent infections and rates of cervical lesions after excisional treatment. Am J Obstet Gynecol 215: 212.e1-212.e15, 2016.
4. Gill SS, Jana AM, Shrivastav A, Sharma S and Sharma A: The carcinogenic potential of E6\& E7 genes of high-risk HPV compared with E6, E7 genes of low-risk HPV in human cervical cancer: A review. Int J Pharm Sci Res 5: 703-712, 2014.

5. Karanikas V, Zamanakou M, Kerenidi T, Dahabreh J, Hevas A, Nakou M, Gourgoulianis KI and Germenis AE: Indoleamine 2,3-dioxygenase (IDO) expression in lung cancer. Cancer Biol Ther 6: 1258-1262, 2007.

6. Bagarazzi ML, Yan J, Morrow MP, Shen X, Parker RL, Lee JC, Giffear M, Pankhong P, Khan AS, Broderick KE, et al: Immunotherapy against HPV16/18 generates potent TH1 and cytotoxic cellular immune responses. Sci Transl Med 4: 155ra138, 2012.

7. Amador-Molina A, Hernández-Valencia JF, Lamoyi E, Contreras-Paredes A and Lizano M: Role of innate immunity against human papillomavirus (HPV) infections and effect of adjuvants in promoting specific immune response. Viruses 5: 2624-2642, 2013.

8. Vidal JP, Felix SP, Chaves CB, Patury P, Franco VF, de Morais EA, de Carvalho NA, Carvalho AC, Almeida Neto OF, Vieira LM, et al: Genetic diversity of HPV16 and HPV18 in Brazilian patients with invasive cervical cancer. J Med Virol 88: 1279-1287, 2016

9. Reuschenbach M, Waterboer T, Einenkel J, Wallin K-L, Dillner J, Heilig B, Hamsikova E, Pawlita M, von Knebel Doeberitz M and Wentzensen N: Characterization of humoral immune responses against p16 in HPV-associated and non HPV-associated disease. Cancer Res 68 (Suppl 9): 2126, 2008.

10. Cilfone NA, Ford CB, Marino S, Mattila JT, Gideon HP, Flynn JL, Kirschner DE and Linderman JJ: Computational modeling predicts IL-10 control of lesion sterilization by balancing early host immunity-mediated antimicrobial responses with caseation during mycobacterium tuberculosis infection. J Immunol 194: 664-677, 2015.

11. Ekalaksananan T, Malat P, Pientong C, Kongyingyoes B, Chumworathayi B and Kleebkaow P: Local cervical immunity in women with low-grade squamous intraepithelial lesions and immune responses after abrasion. Asian Pac J Cancer Prev 15: 4197-4201, 2014.

12. Bergner S, Halec G, Schmitt M, Aubin F, Alonso A and Auvinen E: Individual and complementary effects of human papillomavirus oncogenes on epithelial cell proliferation and differentiation. Cells Tissues Organs 201: 97-108, 2016.

13. Palacios F, Moreno P, Morande P, Abreu C, Correa A, Porro V, Landoni AI, Gabus R, Giordano M, Dighiero G, et al: High expression of AID and active class switch recombination might account for a more aggressive disease in unmutated CLL patients: Link with an activated microenvironment in CLL disease. Blood 115: 4488-4496, 2010.

14. Zhang M, Liu Y, Liu S, Zhang B, Si J, Xu X, Chen L and Song G: Assay and L1 gene sequence analysis of human papillomavirus type 6 and 11 in condylomata acuminata. Zhongguo Yi Xue Ke Xue Yuan Xue Bao 22: 463-466, 2000 (In Chinese).

15. Livak KJ and Schmittgen TD: Analysis of relative gene expression data using real-time quantitative PCR and the 2(-Delta Delta C(T)) method. Methods 25: 402-408, 2001.

16. Landoni F, Colombo A, Milani R, Placa F, Zanagnolo V and Mangioni C: Randomized study between radical surgery and radiotherapy for the treatment of stage IB-IIA cervical cancer: 20-year update. J Gynecol Oncol 28: e34, 2017.

17. Leto M, Santos Júnior GF, Porro AM and Tomimori J: Human papillomavirus infection: Etiopathogenesis, molecular biology and clinical manifestations. An Bras Dermatol 86: 306-317, 2011.

18. Jiménez-Wences H, Martínez-Carrillo DN, Peralta-Zaragoza O, Campos-Viguri GE, Hernández-Sotelo D, Jiménez-López MA, Muñoz-Camacho JG, Garzón-Barrientos VH, Illades-Aguiar B and Fernández-Tilapa G: Methylation and expression of miRNAs in precancerous lesions and cervical cancer with HPV16 infection. Oncol Rep 35: 2297-2305, 2016.

19. Wagner M, Bennetts L, Patel H, Welner S, de Sanjose S and Weiss TW: Global availability of data on HPV genotype-distribution in cervical, vulvar and vaginal disease and genotype-specific prevalence and incidence of HPV infection in females. Infect Agent Cancer 10: 13, 2015.

20. Araujo-Neto AP, Ferreira-Fernandes H, Amaral CMM, Santos LG, Freitas AC, Silva-Neto JC, Rey JA, Burbano RR, Silva BB, Yoshioka FKN, et al: Lack of detection of human papillomavirus DNA in prostate carcinomas in patients from northeastern Brazil. Genet Mol Biol 39: 24-29, 2016. 
21. Vuitton DA, Azizi A, Richou C, Vuitton L, Blagosklonov O, Delabrousse E, Mantion GA and Bresson-Hadni S: Current interventional strategy for the treatment of hepatic alveolar echinococcosis. Expert Rev Anti Infect Ther 14: 1179-1194, 2016.

22. Chung EY, Liu J, Zhang Y and Ma X: Differential expression in lupus-associated IL-10 promoter single-nucleotide polymorphisms is mediated by poly(ADP-ribose) polymerase-1. Genes Immun 8: 577-589, 2007 .

23. Naing A, Papadopoulos KP, Autio KA, Ott PA, Patel MR, Wong DJ, Falchook G, Pant S, Whiteside M, Rasco D, et al: Anti-tumor activity of PEGylated human IL-10 (AM0010) in renal cancer alone and in combination with anti-PD1. Ann Oncol 27: 364PD, 2016

24. Barbisan G, Pérez LO, Contreras A and Golijow CD: TNF- $\alpha$ and IL-10 promoter polymorphisms, HPV infection, and cervical cancer risk. Tumour Biol 33: 1549-1556, 2012.
25. Kemmerling R, Weyland D, Kiesslich T, Illig R, Klieser E, Jäger T, Dietze O and Neureiter D: Robust linear regression model of Ki-67 for mitotic rate in gastrointestinal stromal tumors. Oncol Lett 7: 745-749, 2014.

26. Muñoz N, Hernandez-Suarez G, Méndez F, Molano M, Posso H, Moreno V, Murillo R, Ronderos M, Meijer C and Muñoz A; Instituto Nacional de Cancerología HPV Study Group: Persistence of HPV infection and risk of high-grade cervical intraepithelial neoplasia in a cohort of Colombian women. Br J Cancer 100: 1184-1190, 2009.

This work is licensed under a Creative Commons Attribution-NonCommercial-NoDerivatives 4.0 International (CC BY-NC-ND 4.0) License. 